\title{
Monitoring the nutritional status of the UK population
}

\section{By Sylvia J. Darke, Department of Health and Social Security, Elephant and Castle, London SE $16 B Y$}

The infinitive 'to monitor' is derived from the Latin monēre: to warn. Government needs to be warned about nutritional status because a food and welfare policy which ensures the health and well-being of a nation must be based on sound nutritional and economic evidence. There is no single measurement upon which an assessment of nutritional status can be based and therefore information must be gathered from a number of sources. In addition, the collection of information must be a continuous process since the effects of nutrition in terms of the national health may be both short and long-term. A distinction must also be made between indicators of nutritional status for population groups either in terms of food supplies or of health, and direct assessment of nutritional status of individuals by surveys and other special studies.

\section{Indicators of nutritional status}

The so-called 'running indices' of nutrition are collected routinely by different Government departments and provide information about either food supplies or different aspects of health.

Food supply statistics. The Ministry of Agriculture, Fisheries and Food publishes annually (a) Food Consumption Level Estimates of the total amount of food available at the dock side and farm gate, and (b) the National Fooci Survey figures which show, for a sample of some $75^{\circ}$ households each year, the amounts and cost of food purchased over a period of one week for domestic consumption. The Family Expenditure Survey carried out by the Office of Population Censuses and Surveys includes money spent on food/head of the population per week.

Health statistics. Birth statistics (perinatal mortality, stillbirth and low birth weight) and mortality statistics, are supplied by the Office of Population Censuses and Surveys. Although they depend on many factors other than nutrition, nevertheless, they are useful because they reveal the circumstances of those groups which can be considered as 'at risk'. Information about self-reported illness, either chronic or short-term, is obtained from the General Household Survey of the Office of Population Censuses and Surveys. Morbidity statistics from the Hospital In-Patient Enquiry monitor diseases of under and over-nutrition seen in hospitals. Measurements of height and weight of schoolchildren are still made routinely at school entry and school leaving and are analysed centrally by the Scottish Home and Health Department but not in England and Wales. Area Directors of the Blood Transfusion Service make monthly returns to us of the number of new female 
volunteer blood donors of child-bearing age who are rejected because their haemoglobin is below $85 \%$. The figures give an assessment, very approximately, of anaemia in women of child-bearing age.

\section{Assessment of nutritional status: nutrition surveys}

Nutritional status depends not only on the amount of food eaten but also on how much of the food is absorbed and on individual requirements, which for most nutrients, let alone foods, are largely unknown. When, as in the developed countries, a sufficient food supply is assured there is no simple yardstick by which to judge nutritional status from dietary intakes alone and a medical assessment of each individual becomes necessary. Studies in depth should be complemented by anthropometry, biochemistry, haematology and socio-economic information.

Nutrition surveys have been made by Government departments, by academic departments of Universities and Medical Schools and by research groups under the aegis of the Medical Research Council. Our studies are of people of different ages with an emphasis on groups likely to be at risk of under-nutrition (Table $\mathrm{r}$ ). In the pre-schoolchildren and the elderly $1973-74$ surveys the sample was designed to be nationally representative, in the others the subjects were randomly selected from

\section{Table I. Department of Health and Social Security Nutrition Surveys}

\begin{tabular}{|c|c|c|c|c|c|c|c|c|c|}
\hline \multirow{3}{*}{$\begin{array}{l}\text { Year } \\
\text { of } \\
\text { survey }\end{array}$} & \multirow[b]{3}{*}{ Subjects } & \multirow{3}{*}{$\begin{array}{c}\text { Age } \\
\text { (years) }\end{array}$} & \multirow{3}{*}{$\begin{array}{c}\text { Number } \\
\text { in } \\
\text { sample }\end{array}$} & \multicolumn{6}{|c|}{ Information collected } \\
\hline & & & & \multirow{2}{*}{$\begin{array}{l}\text { Socio- } \\
\text { economic }\end{array}$} & \multirow{2}{*}{$\begin{array}{c}\text { Dietary } \\
7 \mathrm{~d} \\
\text { weighed }\end{array}$} & \multirow{2}{*}{$\begin{array}{c}\text { Medical } \\
\text { assess- } \\
\text { ment }\end{array}$} & \multicolumn{3}{|c|}{ Anthropometry } \\
\hline & & & & & & & Ht. & Wt. & Skinfold \\
\hline $1967-68$ & $\begin{array}{l}\text { Pre-school- } \\
\text { children }\end{array}$ & $\frac{1}{2}-4 \frac{1}{2}$ & 1321 & t & $t$ & $\begin{array}{l}\text { about } \\
10 \%\end{array}$ & + & + & - \\
\hline 1971 & Schoolchildren & $10-11$ & 321 & + & + & + & + & + & + \\
\hline & families & $14-15$ & I 78 & + & + & + & + & + & + \\
\hline $\begin{array}{l}1970-71 \\
1967-68\end{array}$ & $\begin{array}{l}\text { Schoolchildren } \\
\text { Pregnant }\end{array}$ & $14-15$ & 792 & + & + & + & + & + & + \\
\hline & women & & 435 & + & + & + & + & + & - \\
\hline $1967-68$ & Elderly & $\begin{array}{l}65 \text { and } \\
\text { over }\end{array}$ & 879 & + & + & + & + & + & + \\
\hline $1972-73$ & Elderly• & $\begin{array}{l}70 \text { and } \\
\text { over }\end{array}$ & 433 & + & + & + & + & + & + \\
\hline $1973-74$ & Elderly" & $\begin{array}{l}65 \text { and } \\
\text { over }\end{array}$ & I 506 & + & + & + & + & + & + \\
\hline $1977-78$ & Elderly ${ }^{\bullet}$ & $\begin{array}{l}75 \text { and } \\
\text { over }\end{array}$ & & + & + & + & + & + & + \\
\hline
\end{tabular}

-Studies of the elderly, but not of other groups, also included biochemistry, haematology and radiology of the metacarpals.

an area or areas chosen both because a nutritional problem was thought to exist there, and because local specialists within the National Health Service were willing to co-operate. Most of the studies were cross-sectional but the survey in 1967-68 of elderly people living in their own homes or with relatives was repeated in 
1 $972-73$ when $32 \%$ had died, $90 \%$ of the original participants who were still alive again provided some information and some $60 \%$ co-operated fully in all aspects of the study. Preparations are now in hand for a ro year follow-up in 1977-78. The analysis of this longitudinal study of the elderly will, it is hoped, also throw light on some of the problems of the ageing process.

We are aware that these studies made in the late 1960 s and early 1970 provide base-line information for a period of relative affluence against which the results of future studies can be compared. Whether or not further studies will be made either by the Department or by other workers in the immediate future is not clear. In terms of resources in time and personnel this type of study is expensive

\section{Special studies}

These have been made either because further knowledge was needed in order to evaluate survey findings, or because other workers have reported results which are of nutritional significance or, on at least one occasion, because the effects of some change in Government food or welfare policy needed to be assessed. Studies made during the last 10 years include the investigation of anaemia in pre-schoolchildren (MacWilliam, 1968) and in women (Elwood, 1968); serum alkaline phosphatase in pre-schoolchildren (Stephen \& Stephenson, 1971); tongue changes in reported vitamin deficiency (Yudkin, Norman, Wilkinson \& Berry, 1970; Berry and Darke, 1972).

In October 1970 the Government announced changes in the provision of school and welfare milk and from April I97 I the daily half-price pint of milk ceased to be available to all pregnant women and children under five years of age, although more families qualified for a daily pint of milk free of charge. School milk was cancelled for all children from 7 years of age except for handicapped children and those who required it for special medical reasons.

Changes in nutritional status could not with certainty be either predicted or denied. Therefore special growth studies of pre-schoolchildren and of schoolchildren, and a study of the health of expectant mothers during pregnancy and of the babies born to them were commissioned, in implementation of the Rothschild report (1971), from outside academic departments. The studies have been so designed that they can be long-term. However, any changes which these studies eventually reveal cannot be ascribed solely to alterations in the provision of milk since there have also been changes in economic and industrial circumstances.

\section{Findings and present problems}

(a) 'Running indices'. Results from the 'running indices' of food supplies continue to show that adequate supplies are available in the United Kingdom. Those for health show a steady improvement in perinatal mortality and other birth statistics, in the low birth weight rate and in growth rates of children. But gradients in height and weight associated with family size, and social and economic differences still persist. Children from small families and Registrar General social classes I and II on average grow to be taller and heavier and fewer 
die in infancy compared with children from large families and Registrar General social classes IV and V. Results from the Scottish Home and Health Department statistics for schoolchildren, from our own surveys and from the commissioned special growth studies of pre-schoolchildren and of schoolchildren (unpublished) all confirm that these gradients for height and weight apply throughout childhood. Many fall into the temptation to ascribe these differences solely to nutrition.

(b) Nutrition surveys. Such an explanation is not confirmed by the findings of our surveys. Among the children surveyed there were no clinical signs of deficiency. A subjective medical assessment based on the criteria set out in the International Biological Programme (IBP) handbook categorized the vast majority as of good nutritional status, $\mathrm{I}-4 \%$ as of average status and none as of 'poor' status. In contrast $4-8 \%$ of the children were described as obese. Average daily intakes of energy and most nutrients were not consistently less in children from large families or in those from Registrar General social classes IV and V (Department of Health and Social Security, 1975; and unpublished surveys). Intakes of vitamin $\mathrm{C}$ did show a consistent decrease with increasing family size and fall in Registrar General social class, but there were no signs of deficiency in any of the children. Apart from genetic influences, there are other factors within the microcosmos of the family which affect growth. These include the relationship and interaction between the child and mother and with other members of the family, and the amount of stimulation the child receives from the external environment (Sosa, Kennell, Klaus \& Urrutia, 1976).

In the $1967-68$ elderly survey about $3 \%$ of subjects over the age of 65 were thought to be undernourished and in well over $2 \%$ the deficiency was associated with non-nutritional clinical disease (Department of Health and Social Security, 1972). The geriatricians agreed that there was a small problem of vitamin D deficiency especially among the housebound elderly. In the repeat study 5 years later the percentage of undernourished had risen but again the condition was almost exclusively in conjunction with other illness. Scurvy was diagnosed in two of the 841 participants who were medically examined in $1967-68$, and in two more the condition was suspected. In $1972-73$ three cases of scurvy were suspected and some subjects had evidence of plasma and leucocyte vitamin $\mathrm{C}$ concentrations below those usually regarded as the lower limits of normal. One of the aims of the surveys was to establish reference ranges for biochemical and haematological measurements in the healthy elderly in the hope that such ranges will be of use in detecting subclinical malnutrition.

(c) Special studies. Nutritional problems among the young have also been highlighted. Late in 1972 a medical officer from the Department visited paediatric departments all over the country and reported a steady increase in the number of young bottle-fed infants admitted to hospital with convulsions which proved to be associated with hypernatraemic dehydration. The report tallied with those published in scientific journals and in 1973 a Working Party of the Department's Advisory Panel on Child Nutrition reviewed infant feeding practice in the United Kingdom. As a result 'Present-day practice in infant feeding' was published 
(Department of Health and Social Security, 1974a) and recommended that breast feeding should be encouraged preferably for $4-6$ months and that unmodified cows' milk was not a suitable artificial feed for many infants under the age of 6 months. Early in 1975 a study of infant feeding practice was commissioned from the Office of Population Censuses and Surveys to ascertain the facts upon which the Department's policy of promoting breast feeding can be further implemented.

Overt nutritional rickets has again been reported, chiefly among Asian immigrants. Rickets was probably the commonest form of malnutrition in this country before the Second World War, and to all intents and purposes disappeared with the introduction in 1940 of cheap or free cod-liver oil and fortified baby foods. But the disease was never completely eradicated and occurred in the Glasgow area in the 1960 . In this decade cases of clinical rickets have been reported from several industrial cities chiefly among Asian immigrants, especially young children, and in some Asian adolescents and young pregnant women (Dawson \& Mondhe, 1972; Arneil, 1975; Preece, Tomlinson, Ribot, Pietrek, Korn, Davies, Ford, Dunnigan \& O'Riordan, 1975; Ford, McIntosh, Butterfield, Preece, Pietrek, Arrowsmith, Arthurton, Turner, O'Riordan \& Dunnigan, 1976). Rickets is not a notifiable disease; hence incidence figures on a national scale are difficult to ascertain. Recently the Department contacted Area Medical Officers and Community Physicians (Child Health) and replies were obtained from all ninety areas. These replies confirmed that the problem of rickets is confined chiefly to Asians in urban areas, particularly in the Midlands and the North and in a few London areas. The replies also indicated that in most areas there is evidence of some osteomalacia among both the Asian and indigenous housebound elderly.

Any discussion of the nutritional status of the UK population would be incomplete without reference to other conditions for which nutrition may in part be responsible, and which appear to be related to what has come to be known as the 'Western-type diet of an affluent society', affluent at least by comparison with two-thirds of the world. Until the economic recession of the past few years obesity was considered to be the most common manifestation of malnutrition in the UK. We have no national statistics, and a recent joint report by the Department of Health and Social Security and the Medical Research Council (1976) discusses areas for further research in the problems of obesity.

The principal cause of death in England is from heart disease especially from coronary heart disease (CHD). Epidemiological evidence suggests that CHD is associated with the 'Western way of life'. Both the report from the Committee on Medical Aspects of Food Policy (Department of Health and Social Security, 1974 $b$ ) and the report from a Working Party of the Royal College of Physicians and the British Cardiac Society (1976) discuss the role of the different dietary factors and both emphasize the importance of considering all risk factors in relation to mortality from the disease. There is a danger in distorting the evidence by singling out one risk factor. To do so is both confusing and misleading to the public.

Other papers in this symposium discuss the broader aspects of dietary fibre, fat and the complex carbohydrates in relation to health and disease. 


\section{Conclusion}

Two-thirds of the world are faced with problems of starvation and malnutrition. In this country we are mostly confronted by problems of excess and of an imbalance in the dietary mixture of foods. There is also a problem of deficiency among some Asians and housebound elderly. Nutritional problems can be dealt with either by changes in national policy or locally by area health authorities. Alterations in national policy are in general reserved for problems which affect the national health and which can only be solved by Government action, for example, a rationing system or welfare policy. Area health authorities can deal more flexibly and often more economically with local problems. Whichever route is employed, action must be based on sound evidence and on sound nutrition education. For this, research and monitoring of nutritional status must be continuous. It is as well to remind ourselves that the public health means the health of 56000000 people and also that the effects of changes in nutritional policy may not reveal themselves for a generation. Admittedly action cannot always wait until all information is well-documented but, when there is intervention, all relevant facts must be taken into account and, in a democracy, we must ensure that the public are wellinformed and are therefore able to make a wise choice.

\section{REFERENCES}

Arneil, G. C. (1975). Proc. Nutr. Soc. 34, 101.

Berry, W. T. C. \& Darke, S. J. (1972). Age and ageing 1, 177.

Dawson, K. P. \& Mondhe, M. S. (1972). Practitioner 208, 709.

Department of Health and Social Security (1972). Rep. pub. Hlth. and Med. Subj., no. 123. London: HM Stationery Office.

Department of Health and Social Security (1974a). Rep. Hlth and Soc. Subj., no. 9. London: HM Stationery Office.

Department of Health and Social Security (1974b). Rep. Hlth. and Soc. Subj., no. 7. London: HM Stationery Office.

Department of Health and Social Security (1975). Rep. Hlth. and Soc. Subj, no. ro. London: HM Stationery Office.

Department of Health and Social Security/Medical Research Council (1976). Research on Obesity. London: HM Stationery Office.

Elwood, P. C. (1968). Proc. Nutr. Soc. 27, 14.

Ford, J. A., McIntosh, W. B., Butterfield, R., Preece, M. A., Pietrek, J., Arrowsmith, W. A., Arthurton, M. W., Turner, W., O'Riordan, J. L. H. \& Dunnigan, M. G. (1976). Arch. Dis. Childh. 51, 939.

MacWilliam, K. (1968). Rep. publ. Hlth. and med. Subj., no. 118, Appendix H. London: HM Stationery Office.

Preece, M. A., Tomlinson, S., Ribot, C. A., Pietrek, J., Korn, H. T., Davies, D. M., Ford, J. A., Dunnigan, M. G. \& O'Riordan, J. L. H. (1975). Quart. f. Med. 44, 575.

Rothschild, Lord N. M. V. (197I). The Organization and Management of Government Research and Development. London: HM Stationery Office.

Sosa, R., Kennell, J. H., Klaus, M. \& Urrutia, J. J. (1976). In Breast Feeding and the Mother, p. I 79 (Ciba Foundation Symposium 45). Amsterdam: Elsevier.

Stephen, J. M. L. \& Stephenson, P. (1971). Archs. Dis. Childh. 46, 185.

Working Party of the Royal College of Physicians of London and the British Cardiac Society (1976). J. R. Coll. Phycns. 10, No. 3.

Yudkin, J., Norman, D. H., Wilkinson, M. E. \& Berry, W. T. C. (1970). Proc. Nutr. Soc. 29, 8A. 